\title{
Complete genome sequence of Thermotoga sp. strain RQ7
}

\author{
Zhaohui $\mathrm{Xu}^{1 *}$, Rutika Puranik', Junxi Hu${ }^{1,2}, \mathrm{Hui} \mathrm{Xu}^{1}$ and Dongmei Han ${ }^{1}$
}

\begin{abstract}
Thermotoga sp. strain RQ7 is a member of the family Thermotogaceae in the order Thermotogales. It is a Gram negative, hyperthermophilic, and strictly anaerobic bacterium. It grows on diverse simple and complex carbohydrates and can use protons as the final electron acceptor. Its complete genome is composed of a chromosome of 1,851,618 bp and a plasmid of $846 \mathrm{bp}$. The chromosome contains 1906 putative genes, including 1853 protein coding genes and 53 RNA genes. The genetic features pertaining to various lateral gene transfer mechanisms are analyzed. The genome carries a complete set of putative competence genes, 8 loci of CRISPRs, and a deletion of a well-conserved Type II R-M system.
\end{abstract}

Keywords: Thermotoga, T. sp. strain RQ7, Natural competence, CRISPR, Restriction-modification system, TneDI, CP007633

\section{Background}

Thermotoga species are a group of thermophilic or hyperthermophilic bacteria that can ferment a wide range of carbohydrates and produce hydrogen gas as one of the major final products $[1,2]$. Their hydrogen yield from glucose can reach the theoretical maximum: $4 \mathrm{~mol}$ of $\mathrm{H}_{2}$ from each mole of glucose [2,3], which makes them ideal candidates for biofuel production. Meanwhile, because their enzymes are thermostable by nature, they also hold great prospect in the biocatalyst sector. 16S rRNA gene sequence analyses place Thermotoga at a deep branch in the tree of life, and genomic studies also reveal extensive horizontal gene transfer events between Thermotogales and other groups, particularly Archaea and Firmicutes [4]. Controversy over the phylogenetic significance of Thermotoga has triggered a prolonged debate on the concepts of species and biogeography, etc. [5].

We have been interested in the genetics of Thermotoga over the years and have developed the earliest set of tools to genetically modify these bacteria [6-8]. Strain RQ7 plays an essential role in these studies. This strain possesses the smallest known plasmid, pRQ7 (846 bp) [9], that is absent from most Thermotoga strains and serves as the base vector for all Thermotoga-E. coli shuttle vectors developed so far. $T$. sp. strain RQ7 is also

\footnotetext{
* Correspondence: zxu@bgsu.edu

${ }^{1}$ Department of Biological Sciences, Bowling Green State University, Bowling Green, $\mathrm{OH}$ 43403, USA

Full list of author information is available at the end of the article
}

the first Thermotoga strain in which natural competence was discovered [7]. To gain insights into the genetic and genomic features of the strain and to facilitate the continuing effort on developing genetic tools for Thermotoga, we set out to sequence the whole genome of $T$. sp. strain RQ7.

\section{Organism information Classification and features}

$T$. sp. strain RQ7 was isolated from marine sediments of Ribeira Quente, Azores [1]. The strain is a member of the genus Thermotoga, the family Thermotogaceae, and the order Thermotogales (Table 1). Based on 16S rRNA gene sequences, the closest relative of $T$. sp. strain RQ7 is T. neapolitana DSM 4359, and these two strains cluster with T. maritima MSB8 and T. sp. strain RQ2 (Fig. 1). The results are in agreement with previous reports [10].

Like its close relatives $T$. neapolitana DSM 4359 and T. maritima MSB8, T. sp. strain RQ7 is a strict anaerobe, growing best around $80{ }^{\circ} \mathrm{C}$, utilizing both simple and complex sugars, and producing hydrogen gas. These bacteria grow in both rich and defined media, are free living and non-pathogenic to humans, animals, or plants. Cells are rod-shaped, about 0.5 to $2 \mu \mathrm{m}$ in length and 0.4 to $0.5 \mu \mathrm{m}$ in diameter (Fig. 2). The most distinctive feature of Thermotoga cells is the "toga" structure that

(c) The Author(s). 2017 Open Access This article is distributed under the terms of the Creative Commons Attribution 4.0 International License (http://creativecommons.org/licenses/by/4.0/), which permits unrestricted use, distribution, and reproduction in any medium, provided you give appropriate credit to the original author(s) and the source, provide a link to the Creative Commons license, and indicate if changes were made. The Creative Commons Public Domain Dedication waiver (http://creativecommons.org/publicdomain/zero/1.0/) applies to the data made available in this article, unless otherwise stated. 
Table 1 Classification and general features of Thermotoga sp. strain RQ7 according to the MIGS recommendations [36]

\begin{tabular}{|c|c|c|c|}
\hline MIGS ID & Property & Term & Evidence code $^{a}$ \\
\hline & Classification & Domain Bacteria & TAS [37] \\
\hline & & Phylum Thermotogae & $\operatorname{TAS}[38,39]$ \\
\hline & & Class Thermotogae & $\operatorname{TAS}[39,40]$ \\
\hline & & Order Thermotogales & $\operatorname{TAS}[39,41]$ \\
\hline & & Family Thermotogaceae & TAS $[39,42]$ \\
\hline & & Genus Thermotoga & TAS $[1,43,44]$ \\
\hline & & Species T. neapolitana & IGC, TSA $[45,46]$ \\
\hline & & strain: RQ7 & TAS [1] \\
\hline & Gram stain & Negative & TAS [1] \\
\hline & Cell shape & Rod & IDA, TAS [1] \\
\hline & Motility & Motile & IDA, TAS [1] \\
\hline & Sporulation & Not reported & \\
\hline & Temperature range & $55-90^{\circ} \mathrm{C}$ & TAS [1] \\
\hline & Optimum temperature & Around $80^{\circ} \mathrm{C}$ & TAS [1] \\
\hline & pH range; Optimum & $5.5-9 ; 6.5$ & IDA, TAS [1] \\
\hline & Carbon source & Mono- and polysaccharides & IDA, TAS $[1,47,48]$ \\
\hline MIGS-6 & Habitat & Geothermally heated sediments & TAS [1] \\
\hline MIGS-6.3 & Salinity & $0.25-3.75 \% \mathrm{NaCl}(w / V)$ & IDA, TAS [1] \\
\hline MIGS-22 & Oxygen requirement & Anaerobic & IDA, TAS [1] \\
\hline MIGS-15 & Biotic relationship & Free-living & IDA, TAS [1] \\
\hline MIGS-14 & Pathogenicity & Non-pathogen & IDA, TAS [1] \\
\hline MIGS-4 & Geographic location & Azores, Sao Miguel, Ribeira Quente & TAS [1] \\
\hline MIGS-5 & Sample collection & 1985 & NAS \\
\hline MIGS-4.1 & Latitude & Not reported & \\
\hline MIGS-4.2 & Longitude & Not reported & \\
\hline MIGS-4.4 & Altitude & About sea level & NAS \\
\hline
\end{tabular}

${ }^{a}$ Evidence codes - IDA Inferred from Direct Assay, TAS Traceable Author Statement (i.e., a direct report exists in the literature), NAS Non-traceable Author Statement (i.e., not directly observed for the living, isolated sample, but based on a generally accepted property for the species, or anecdotal evidence), IGC Inferred from Genomic Content (i.e., average nucleotide identity, syntenic regions). These evidence codes are from the Gene Ontology project [49]

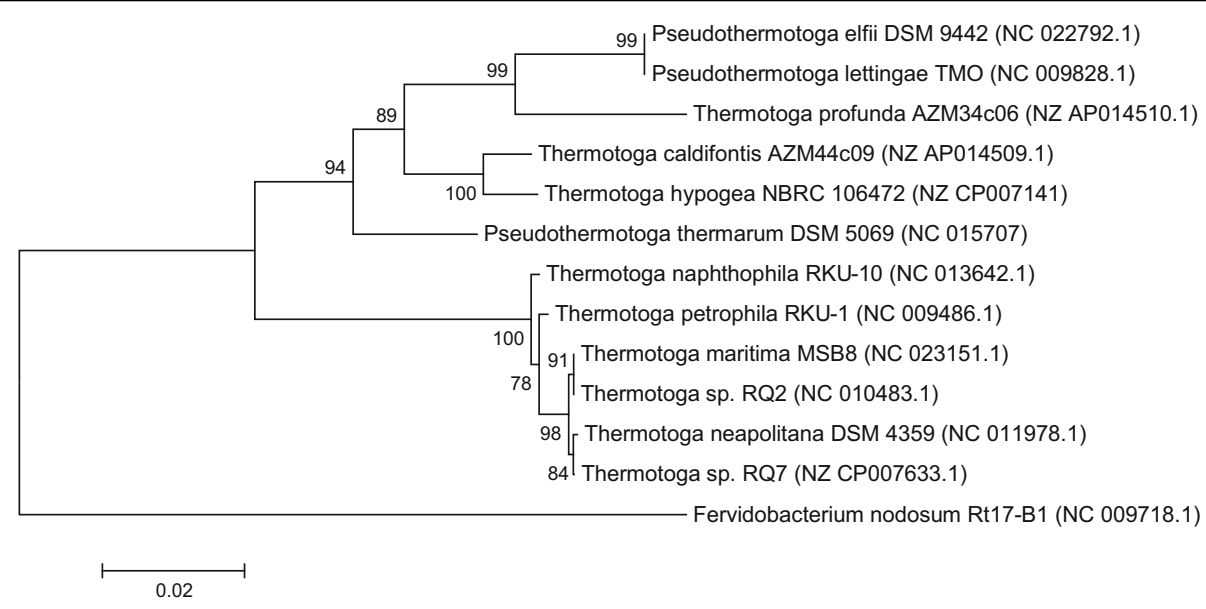

Fig. 1 Phylogenetic tree showing the position of T. sp. strain RQ7 relative to other species within the order Thermotogales. Only species with complete genome sequences are included. The tree was built with 165 rRNA gene sequences, using the Neighbor-Joining method with MEGA7 [50]. Fervidobacterium nodosum serves as the outgroup 


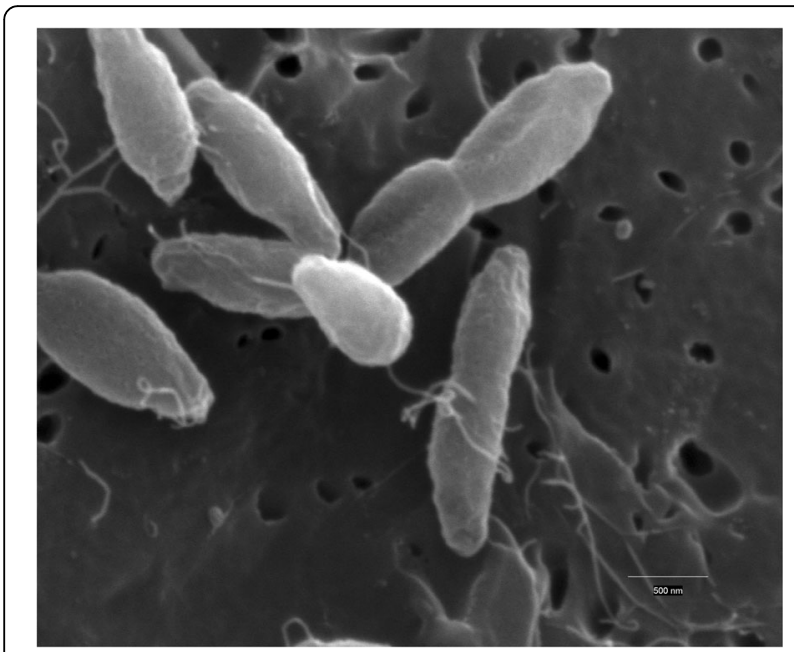

Fig. 2 Scanning electron micrograph of T. sp. strain RQ7 cells after $12 \mathrm{~h}$ of growth. Bar, $0.5 \mu \mathrm{m}$

balloons out from both ends of the rod $[1,11]$, an extension of their outer membrane [12].

\section{Genome sequencing information}

\section{Genome project history}

The project started in June 2011, and the genome was sequenced by BGI Americas (Cambridge, MA) using the Illumina technology. A total of $400 \mathrm{Mb}$ of clean data were generated, which covered the genome more than 200 fold. The assembled scaffold covers $97.7 \%$ of the chromosome. PCR and Sanger sequencing were later used for gap filling. The assembly was finalized in February 2014, and the complete sequence was submitted to the GenBank in April 2014. The sequence was annotated with the NCBI Prokaryotic Genome Annotation Pipeline [13] and the DOE-JGI Microbial Genome Annotation Pipeline (MGAP v.4) [14]. The project information is summarized in Table 2 .

\section{Growth conditions and genomic DNA preparation}

T. sp. strain RQ7 was kindly provided by Drs. Harald Huber and Robert Huber at the University of Regensburg, Germany. It was cultivated in SVO medium [15] at $77^{\circ} \mathrm{C}$, and its genomic DNA was extracted with standard phenol extraction method [16]. Briefly, cells from $250 \mathrm{ml}$ of overnight culture were collected by centrifugation and resuspended in $10 \mathrm{ml}$ of STE solution (10 mM Tris-HCl, $1 \mathrm{mM}$ EDTA, $100 \mathrm{mM} \mathrm{NaCl}$, $\mathrm{pH}$ 8.0). SDS and proteinase $\mathrm{K}$ were added to a final concentration of $1 \%(\mathrm{w} / \mathrm{v})$ and $20 \mu \mathrm{g} / \mathrm{ml}$. The mixture was incubated at $50{ }^{\circ} \mathrm{C}$ for $6 \mathrm{~h}$ followed by the addition of an equal volume of phenol/chloroform/isoamyl alcohol $(25: 24: 1, v / v / v)$. After gentle mixing, the mixture was centrifuged at $12,000 \mathrm{~g}$ at $4{ }^{\circ} \mathrm{C}$ for $15 \mathrm{~min}$. The upper
Table 2 Project information

\begin{tabular}{|c|c|c|}
\hline MIGS ID & Property & Term \\
\hline MIGS 31 & Finishing quality & Complete \\
\hline MIGS-28 & Libraries used & $\begin{array}{l}\text { Three Illumina paired-end libraries } \\
\text { in sizes of 500, 2000, and } 5000 \text { bp }\end{array}$ \\
\hline MIGS 29 & $\begin{array}{l}\text { Sequencing } \\
\text { platforms }\end{array}$ & Illumina and Sanger \\
\hline MIGS 31.2 & Fold coverage & $>200 \times$ \\
\hline MIGS 30 & Assemblers & $\begin{array}{l}\text { SOAPdenovo [17], SOAPaligner [18], } \\
\text { CLC Workbench } 5.1 \text { [19], and } \\
\text { GapFish [20] }\end{array}$ \\
\hline \multirow[t]{6}{*}{ MIGS 32} & $\begin{array}{l}\text { Gene calling } \\
\text { method }\end{array}$ & GeneMarkS+ [51], Prodigal [52] \\
\hline & Locus Tag & $\begin{array}{l}\text { TRQ7 in GenBank; Ga0077854 in } \\
\text { JGI-IMG }\end{array}$ \\
\hline & GenBank ID & CP007633, KF798180 \\
\hline & $\begin{array}{l}\text { GenBank Date } \\
\text { of Release }\end{array}$ & February 4, 2015 \\
\hline & GOLD ID & Gp0117593 \\
\hline & BIOPROJECT & PRJNA246218 \\
\hline \multirow[t]{2}{*}{ MIGS 13} & $\begin{array}{l}\text { Source Material } \\
\text { Identifier }\end{array}$ & $\begin{array}{l}\text { Personal culture collection } \\
\text { (Dr. Harald Huber) }\end{array}$ \\
\hline & Project relevance & Bioenergy, biotechnology, evolution \\
\hline
\end{tabular}

aqueous layer was transferred to a clean tube and mixed with $1 / 10$ volume of $3 \mathrm{M}$ sodium acetate $(\mathrm{pH} 5.5)$ and 2 volumes of ice cold $95 \%(\mathrm{v} / \mathrm{v})$ ethanol. The DNA was spooled out by a glass rod, washed with $70 \%(\mathrm{v} / \mathrm{v})$ ethanol, air dried, dissolved in $2 \mathrm{ml}$ of TE buffer (10 mM Tris- $\mathrm{HCl}, 1 \mathrm{mM}$ EDTA, $\mathrm{pH}$ 8.0) containing $20 \mu \mathrm{g} / \mathrm{ml}$ RNase A, and stored at $-20{ }^{\circ} \mathrm{C}$.

\section{Genome sequencing and assembly}

The genome of $T$. sp. strain RQ7 was mainly sequenced by BGI Americas using Illumina HiSeq 2000 sequencing platform. Three paired-end libraries, in size of 500, 2000, and $5000 \mathrm{~kb}$, were constructed. The raw data were filtered by a quality control step and generated $400 \mathrm{Mb}$ of clean data, which indicated a coverage of more than 200 -fold. The reads were assembled by SOAPdenovo [17] and polished by SOAPaligner [18]. This resulted in a single scaffold of $1,822,593 \mathrm{bp}$ that covered $97.7 \%$ of the genome and contained 28 gaps. The gap filling efforts included the integration of the current scaffold with contigs generated by the CLC Genomics Workbench [19] and a small amount of public sequences in GenBank. GapFish [20] was then used to solve a dozen ambiguous regions. Finally, PCR and primer walking were performed to close the remaining gaps, resulting a final assembly of $1,851,618 \mathrm{bp}$. The entire assembling process integrated wet lab methods with in silico approaches, and the programs used included public software 


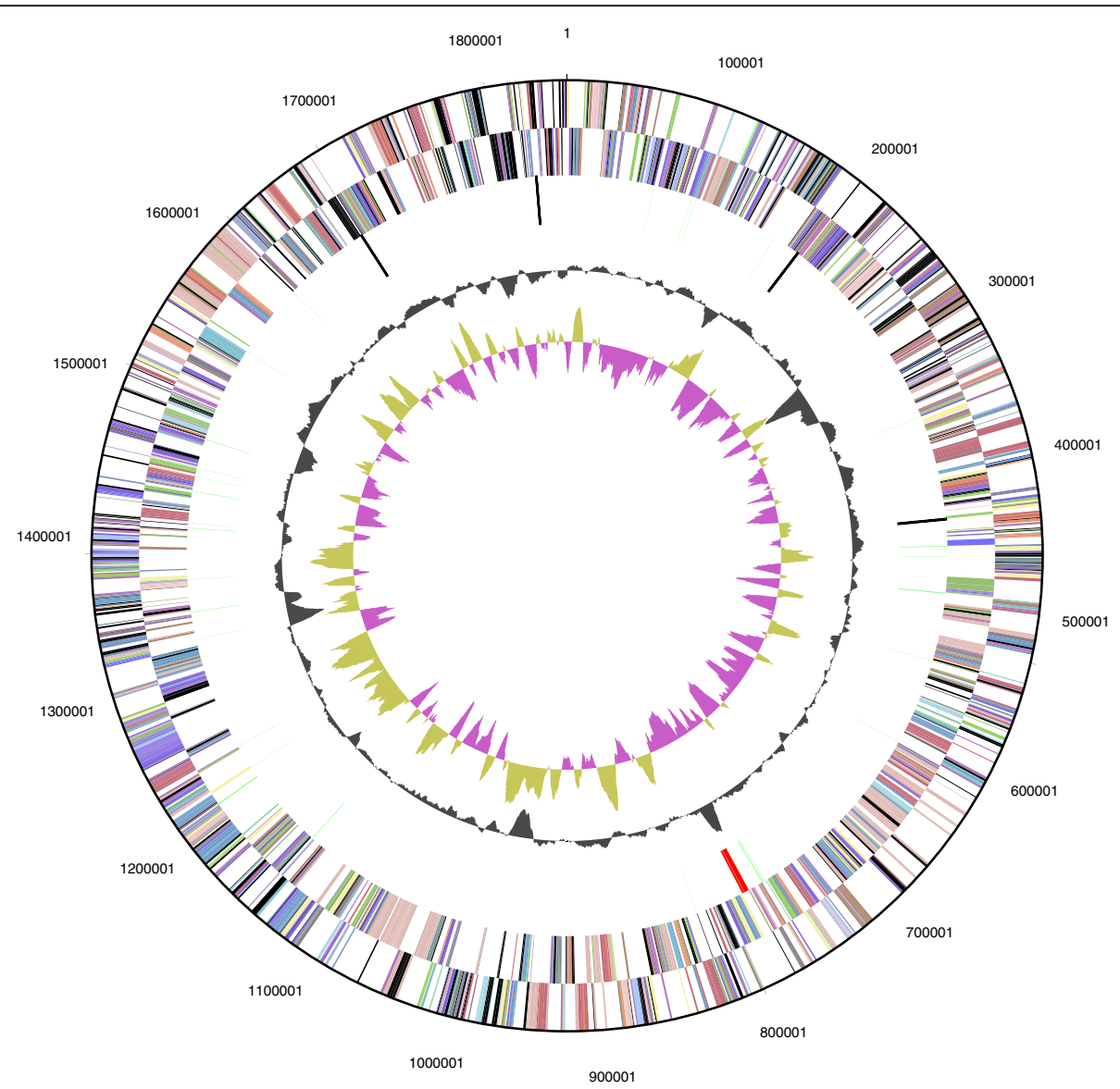

Fig. 3 Chromosomal map of T. sp. strain RQ7. From outside to the center: genes on forward strand (color by COG categories), genes on reverse strand (color by COG categories), RNA genes (tRNAs: green, rRNAs: red, other RNAs: black), GC content (black), GC skew (olive/purple)

(SOAPdenovo and SOAPaligner [17, 18]), a commercial product (CLC Genomics Workbench [19]), and an in-house program GapFish [20]. Details of the assembling process are described in our previous report [20].

\section{Genome annotation}

The genome was independently annotated by two pipelines, the NCBI Prokaryotic Genome Annotation Pipeline [13] and the DOE-JGI Microbial Genome Annotation Pipeline (MGAP v.4) [14]. Both pipelines combine a gene-calling algorithm with a similarity-based gene detection approach, even though the algorithms and databases they use are different. For example, PGAAP uses GeneMarkS+ for de novo gene prediction, while MGAP uses Prodigal. Consequently, the two pipelines produced slightly different annotation results. The analyses in this report took into consideration of the results from both pipelines and are assisted with manual curation.

\section{Genome properties}

The genome of $T$. sp. strain RQ7 is composed of a circular chromosome of $1,851,618$ bp with a GC content of $47.05 \%$ and a single mini-plasmid of 846 bp with a GC percentage of 39.95 (Fig. 3; Table 3). The plasmid pRQ7 has been characterized [9] and sequenced [6, 21] before. According to the annotation of MGAP, the chromosome carries 1906 putative genes, of which, 1853 are protein coding genes and 53 are RNA genes (Table 4). Among all the genes that are assigned to a COG category (Table 5), a significant portion $(\sim 12 \%, 191$ genes) are devoted to carbohydrate utilization, which is typical to Thermotoga strains and accords with their versatile use of carbon and energy sources.

Table 3 Summary of genome: one chromosome and one plasmid

\begin{tabular}{lllll}
\hline Label & Size (bp) & Topology & INSDC identifier & RefSeq ID \\
\hline Chromosome & $1,851,618$ & Circular & CP007633 & NZ_CP007633 \\
pRQ7 & 846 & Circular & KF798180 & NC_023152 \\
\hline
\end{tabular}


Table 4 Genome statistics according to the MGAP pipeline annotation (chromosome only)

\begin{tabular}{lll}
\hline Attribute & Value & \% of total \\
\hline Genome size (bp) & $1,851,618$ & 100.00 \\
DNA coding (bp) & $1,768,561$ & 95.51 \\
DNA G + C (bp) & 871,250 & 47.05 \\
DNA scaffolds & 1 & \\
Total genes & 1906 & 100.00 \\
Protein coding genes & 1853 & 97.22 \\
RNA genes & 53 & 2.78 \\
Pseudo genes & - & - \\
Genes in internal clusters & 110 & 5.77 \\
Genes with function prediction & 1522 & 79.85 \\
Genes assigned to CoGs & 1453 & 76.23 \\
Genes with Pfam domains & 1629 & 85.47 \\
Genes with signal peptides & 35 & 1.84 \\
Genes with transmembrane helices & 462 & 24.24 \\
CRISPR repeats & 8 & \\
\hline
\end{tabular}

\section{Insights from the genome sequence}

The chromosomal sequence of $T$. sp. strain RQ7 was compared to those of $T$. maritima MSB8, $T$. neapolitana DSM 4359, and $T$. sp. strain RQ2, with emphases on the genetic elements that have the highest impacts on genetic engineering attempts, such as natural competence genes, CRISPRs, and R-M systems.

\section{Full genome comparison}

The alignment of the complete genomic sequence of the four Thermotoga strains (Fig. 4) revealed high levels of synteny among their genomes, particularly within the pairs of $T$. sp. strain RQ7-T. neapolitana DSM 4359 and T. sp. strain RQ2-T. maritima MSB8. This is in agreement with their placements in the phylogenetic tree (Fig. 1). The average nucleotide identity between $T$. sp. strain RQ7 and the type strain T. neapolitana DSM 4359 is $98.49 \%$, which is higher than the conventional cutoff of $95 \%$ for species delineation [22]. Therefore, T. sp. strain RQ7 should be considered as a strain of $T$. neapolitana, same as T. sp. strain RQ2 to T. maritima [23].

Table 5 Number of genes associated with general COG functional categories

\begin{tabular}{|c|c|c|c|}
\hline Code & Value & \%age & Description \\
\hline J & 165 & 10.17 & Translation, ribosomal structure and biogenesis \\
\hline A & - & - & RNA processing and modification \\
\hline K & 75 & 4.62 & Transcription \\
\hline L & 53 & 3.27 & Replication, recombination and repair \\
\hline B & 1 & 0.06 & Chromatin structure and dynamics \\
\hline D & 19 & 1.17 & Cell cycle control, Cell division, chromosome partitioning \\
\hline V & 34 & 2.09 & Defense mechanisms \\
\hline $\mathrm{T}$ & 57 & 3.51 & Signal transduction mechanisms \\
\hline M & 74 & 4.56 & Cell wall/membrane biogenesis \\
\hline N & 55 & 3.39 & Cell motility \\
\hline U & 21 & 1.29 & Intracellular trafficking and secretion \\
\hline O & 66 & 4.07 & Posttranslational modification, protein turnover, chaperones \\
\hline C & 104 & 6.41 & Energy production and conversion \\
\hline G & 191 & 11.77 & Carbohydrate transport and metabolism \\
\hline $\mathrm{E}$ & 169 & 10.41 & Amino acid transport and metabolism \\
\hline $\mathrm{F}$ & 65 & 4 & Nucleotide transport and metabolism \\
\hline H & 73 & 4.5 & Coenzyme transport and metabolism \\
\hline । & 42 & 2.59 & Lipid transport and metabolism \\
\hline P & 103 & 6.35 & Inorganic ion transport and metabolism \\
\hline Q & 18 & 1.11 & Secondary metabolites biosynthesis, transport and catabolism \\
\hline $\mathrm{R}$ & 156 & 9.61 & General function prediction only \\
\hline$S$ & 75 & 4.62 & Function unknown \\
\hline - & 453 & 23.77 & Not in COGs \\
\hline
\end{tabular}

The total is based on the total number of protein coding genes in the genome as annotated by MGAP v.4 [14] 


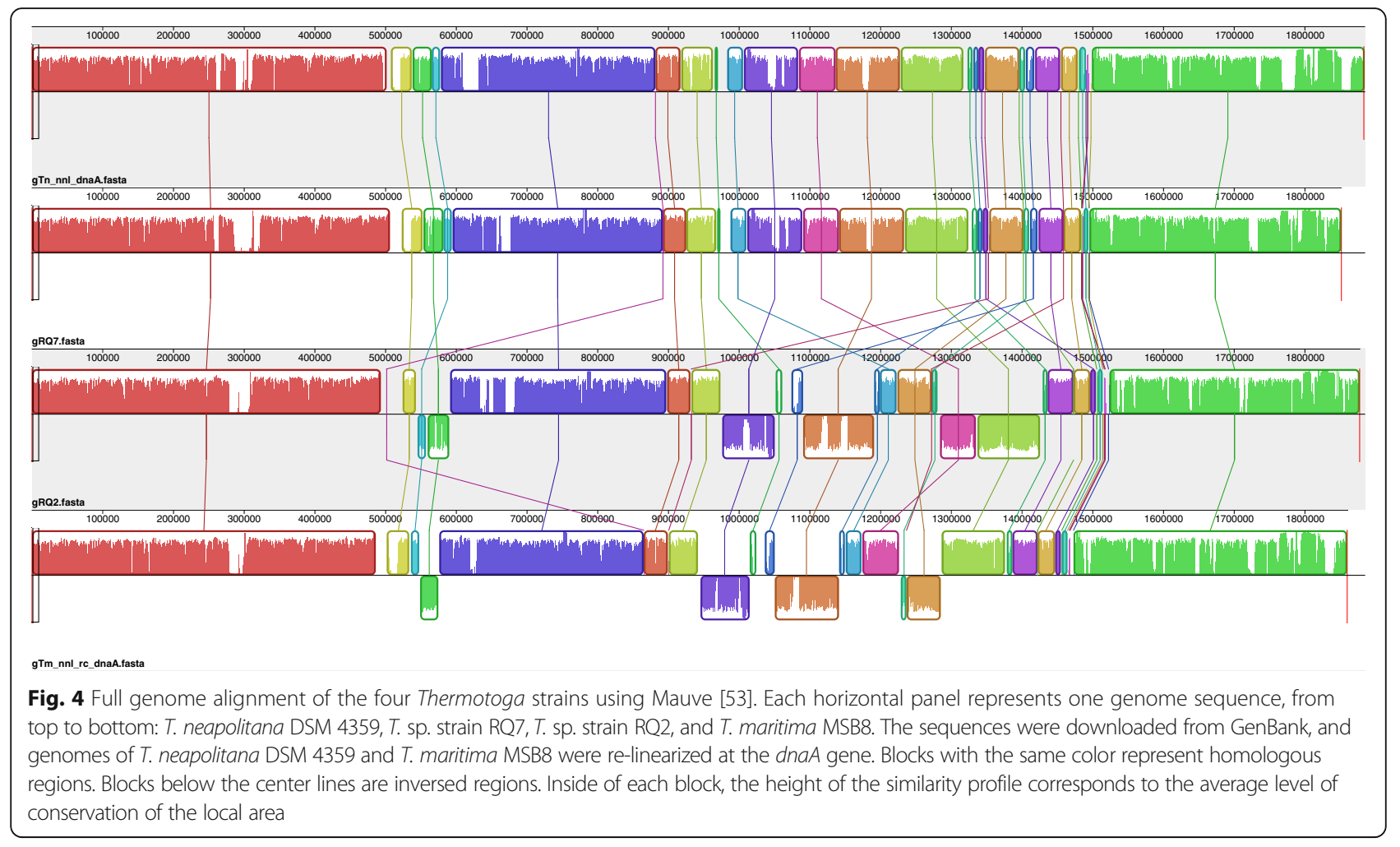

A detailed comparison of $T$. sp. strain RQ7 and T. neapolitana DSM 4359 found 100 genes belonging only to the former and 120 genes only to the latter. Some of these genes became unique because their counterparts in the other genome have mutated to a pseudogene. However, many of the unique genes seem to have been acquired via recent lateral gene transfer events. The putative functions of these genes are mainly associated to transportation and utilization of carbohydrates and nucleotides. The most notable gene clusters include TRQ7_01555-01655 (nucleotide metabolism), TRQ7_02 675-02725 (carbohydrate metabolism), TRQ7_03440-03490 (arabinose metabolism), CTN_0026-0038 (synthesis of antibiotics), CTN_0236-0245 (carbohydrate metabolism), CTN_0355-0373 (ribose metabolism), CTN_1540-1554 (carbohydrate metabolism), and CTN_1602-1627 (ribose metabolism). Follow-up functional genomics studies are needed to validate the predictions on these gene functions and metabolic pathways.

\section{Natural competence}

Thermotoga species are known to undergo lateral gene transfer events. One of the ways this could happen is via natural transformation. Natural competence has been established in T. sp. strain RQ7 [7] and T. sp. strain RQ2 [8]. Using experimentally characterized competence genes as references, we are able to identify the genes that might play a role in natural competence in Thermotoga (Table 6). These genes are widely spread among bacterial genomes, and none of them are clustered into operons. This might imply a primitive form of natural competence that is shared by most, if not all, bacteria. Perhaps, most free-living bacteria are more or less naturally competent during some points of their life. The trick is to identify the right conditions under which the natural competence will be allowed to develop.

\section{CRISPRs}

CRISPRs provide prokaryotes a form of adaptive immunity against invading phages and plasmids in a sequence specific manner [24, 25]. The system utilizes non-coding CRISPR RNA and a set of CRISPR-associated proteins to target invading nucleic acid, including both DNA and RNA. CRISPRs have been reported to prevent natural transformation $[26,27]$. They have been noticed before in Thermotoga and are credited for large scale chromosomal recombination events in these species [28, 29]. NCBI's PGAAP pipeline identified 6 loci of CRISPR arrays in $T$. sp. strain RQ7, whereas JGI-IMG's MGAP pipeline and a manual analysis using CRISPRFinder [30] recognized a total of 8 loci (Table 7). Among these eight CRISPR loci, \#1 and \#3 are the ones not considered by PGAAP. Two clusters of cas genes are also found. The cas6-cas 2 cassette is sandwiched between loci \#3 
Table 6 Manually curated competence genes

\begin{tabular}{|c|c|c|c|c|c|}
\hline RQ7 & Gene name $^{a}$ & Putative function & Tn & $\operatorname{Tm}$ & RQ2 \\
\hline \multicolumn{6}{|c|}{ DNA uptake and translocation } \\
\hline TRQ7_00110 & pilZ $(\mathrm{Pa}, \mathrm{Vc})$ & Type IV pilus biogenesis and twitching motility [54-56] & CTN_1670 & TM0905 & TRQ2_0022 \\
\hline TRQ7_00455 & pilB $(\mathrm{Pa}, \mathrm{Vc})$ & $\begin{array}{l}\text { Type II secretion system (T2SS), Type IV fimbrial assembly } \\
\text { NTPase [57-59] }\end{array}$ & CTN_1739 & TM0837 & TRQ2_0090 \\
\hline $\begin{array}{l}\text { TRQ7_01410 } \\
\text { TRQ7_04530 } \\
\text { TRQ7_08710 }\end{array}$ & pilQ $(\mathrm{Nm}, \mathrm{Tt})$ & $\begin{array}{l}\text { Secretin, forms gated channel for extrusion of assembled } \\
\text { pilin [60-62] }\end{array}$ & $\begin{array}{l}\text { CTN_1450 } \\
\text { CTN_1933 } \\
\text { CTN_0604 }\end{array}$ & $\begin{array}{l}\text { TM1117 } \\
\text { TM0088 }\end{array}$ & $\begin{array}{l}\text { TRQ2_1699 } \\
\text { TRQ2_0859 }\end{array}$ \\
\hline TRQ7_04500 & pilC (Ps, Ng) & $\begin{array}{l}\text { Type II secretory pathway, component PulF / Type IV } \\
\text { fimbrial assembly protein }[63,64]\end{array}$ & CTN_0598 & TM_0094 & TRQ2_0853 \\
\hline TRQ7_05855 & pilD $(\mathrm{V}, \mathrm{Ng})$ & $\begin{array}{l}\text { Type IV prepilin peptidase, processes N-terminal leader } \\
\text { peptides for prepilins [65-67] }\end{array}$ & CTN_0883 & TM1696 & TRQ2_1138 \\
\hline TRQ7_06260 & comEC (Bs) & $\begin{array}{l}\text { Putative channel protein, Transports DNA across the cell } \\
\text { membrane }[68,69]\end{array}$ & CTN_0965 & TM1775 & TRQ2_1049 \\
\hline TRQ7_07315 & $\operatorname{comF}(\mathrm{Hi})$ & Phosphoribosyltransferase $[70,71]$ & CTN_1168 & TM1584 & TRQ2_1247 \\
\hline TRQ7_07650 & pilT (Ng) & Motility protein [72] & CTN_1229 & TM1362 & TRQ2_1467 \\
\hline TRQ7_07980 & pile (Ng, $\mathrm{Pa})$ & $\begin{array}{l}\text { Type IV pilin; major structural component of Type IV } \\
\text { pilus }[73,74]\end{array}$ & CTN_1301 & TM1271 & TRQ2_1548 \\
\hline TRQ7_09065 & comEA (Bs) & High affinity DNA-binding periplasmic protein [75-78] & CTN_1515 & TM1052 & TRQ2_1756 \\
\hline \multicolumn{6}{|c|}{ Post-translocation } \\
\hline TRQ7_02260 & $\operatorname{comM}(\mathrm{Hi})$ & $\begin{array}{l}\text { Promotes the recombination of the donor DNA into the } \\
\text { chromosome [79] }\end{array}$ & CTN_0158 & TM0513 & TRQ2_0424 \\
\hline TRQ7_03645 & $\operatorname{dprA}(\mathrm{Hi})$ & DNA protecting protein $[80,81]$ & CTN_0436 & TM0250 & TRQ2_0698 \\
\hline
\end{tabular}

${ }^{a}$ Gene names are given after the experimentally characterized genes of the species in parentheses. Pa Pseudomonas aeruginosa, $\mathrm{Vc}$ Vibrio cholerae, Nm Neisseria meningitidis, Tt Thermus thermophilus, Ps Pseudomonas stutzeri, Ng Neisseria gonorrhoeae, Vv Vibrio vulnificus, Bs Bacillus subtilis, Hi influenza, RQ7 T. sp. strain RQ7, Tn T. neapolitana DSM 4359, Tm T. maritima MSB8, RQ2 T. sp. strain RQ2

and \#4, and the cas6-csm1 cassette is located $2285 \mathrm{bp}$ upstream of locus \#3 (Fig. 5, Table 7).

Although analysis with CRISPRFinder revealed the same number of CRISPR loci in the four close relatives, i.e. T. sp. strain RQ7, T. neapolitana DSM 4359, T. maritima MSB8, and $T$. sp. strain RQ2, the total number of spacers they carry vary dramatically, as $95,60,106$, and 129 spacers are found respectively. T. maritima MSB8 and $T$. sp. strain RQ2 also harbor RNA-targetting $\mathrm{cmr}$ genes in addition to DNA-targetting cas genes [31]. These differences may affect the efficiency of lateral gene transfer events among the strains.

Table 7 Summary of CRISPR loci in T. sp. strain RQ7

\begin{tabular}{|c|c|c|c|c|}
\hline Locus & Repeats & Coordinates $^{a}$ & No. of spacers & Cas genes \\
\hline 1 & $\begin{array}{l}\text { GTTCAATCCTTCCTTAGAGGTATGGAAACA } \\
\text { GTITCAATACTTCCTIAGAGGTATGGAAACA } \\
\text { GTTCAATACTCCTTGAGGTATGAAAACA }\end{array}$ & $553,849-554,014$ & 2 & No \\
\hline 2 & $\begin{array}{l}\text { TाTCCTATACCTCTAAGAAAGGATTGAAAC } \\
\text { GTTTCCATACCTCTAAGGAAGTATTGAAAC }\end{array}$ & $594,500-594,927$ & 6 & No \\
\hline 3 & $\begin{array}{l}\text { GTTCAATACTTCCTITGAGGTATGGAAA } \\
\text { GTTCAATACTTCCTIAGAGGTATGGAAA } \\
\text { GTTCAATACATCCTCAGAGGTATGATTT }\end{array}$ & $975,191-975,420$ & 3 & Yes \\
\hline 4 & $\begin{array}{l}\text { GTITTATCTTCCTAAGAGGAATATGAAC } \\
\text { GTITITATCTTCCTAAGAGGAATATAGTA }\end{array}$ & $983,596-986,955$ & 51 & Yes \\
\hline 5 & $\begin{array}{l}\text { GTTCAATACTTCCTITGAGGTATGGAAAC } \\
\text { GTTCAATATTTCCTTATAGGTACAAACCC }\end{array}$ & $1,011,410-1,012,101$ & 10 & No \\
\hline 6 & GTTTCAATACTTCCTTAGAGGTATGGAAAC & $1,090,312-1,090,681$ & 5 & No \\
\hline 7 & GTTTCCATACCTCTAAGGAAGTATTGAAAC & $1,233,649-1,233,878$ & 3 & No \\
\hline 8 & GTTTCAATACTTCCTITGAGGTATGGAAAC & $1,422,811-1,423,509$ & 10 & No \\
\hline
\end{tabular}

${ }^{a}$ Coordinates as documented in JGI-IMG. The start coordinates in GenBank are 20 bp smaller because the chromosome is linearized at a site 20 bp downstream of what JGI-IMG uses 


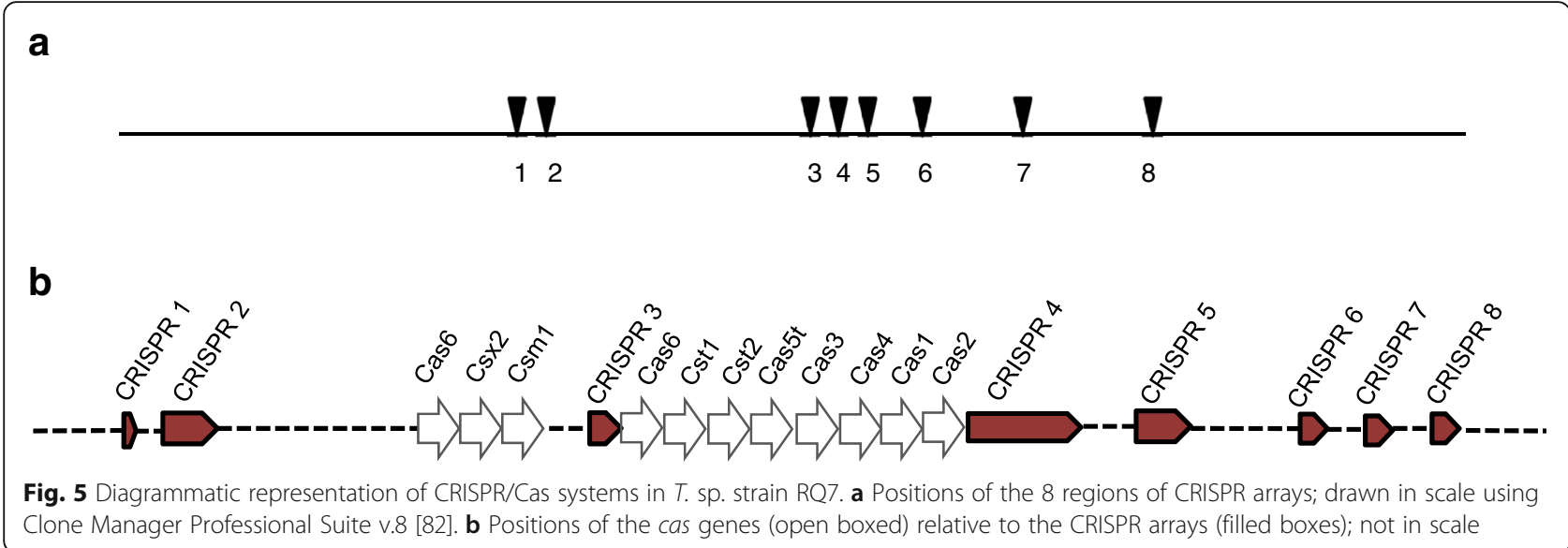

Type II R-M system TneDI

$\mathrm{R}-\mathrm{M}$ systems are other defense mechanisms that prokaryotes have developed to protect the integrity of their genetic materials. The Type II R-M system TneDI has been characterized in T. neapolitana DSM 4359 and overexpressed in Escherichia coli [32, 33]. The nuclease R.TneDI cleaves at the center of the recognition site (CG $\downarrow C G)$, and the methylase M.TneDI modifies one of the cytosines. The TneDI system has been found in many members of the Thermotogaceae family, including T. maritima MSB8 and $T$. sp. strain RQ2 [32]. However, it is absent from $T$. sp. strain RQ7, although the neighborhood is still highly conserved (Fig. 6). To exclude the possibility of an assembling error, primers spanning the region

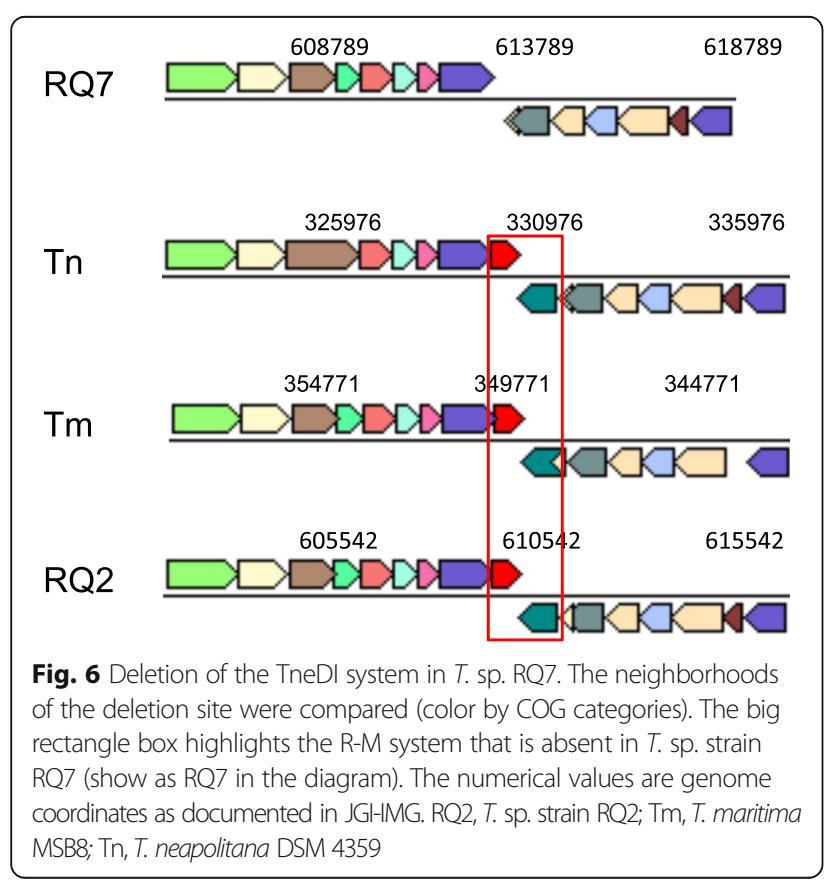

in question were designed, and the PCR results confirmed the deletion (Fig. 7). The absence of the TneDI system makes the DNA of $T$. sp. strain RQ7 susceptible to R.TneDI, and in vitro treatment with M.TneDI provides complete protection to its genomic DNA (Fig. 8).

M.TneDI has been predicted to be a $\mathrm{m}^{4} \mathrm{C}$ methylase based on sequence analysis [32]. It has also been noticed that $\mathrm{m}^{4} \mathrm{C}$ methylation is more common than $\mathrm{m}^{5} \mathrm{C}$ in thermophiles, probably due to a reduced risk of deamination [34]. The speculation of M.TneDI being a $\mathrm{m}^{4} \mathrm{C}$ methylase is further supported by the observation that the genomic DNA of TneDI-bearing species is still suspetible to BstUI (Fig. 9), which is an isoschizomer of R.TneDI and known to be blocked by $\mathrm{m}^{5} \mathrm{C}$ methylation [35].

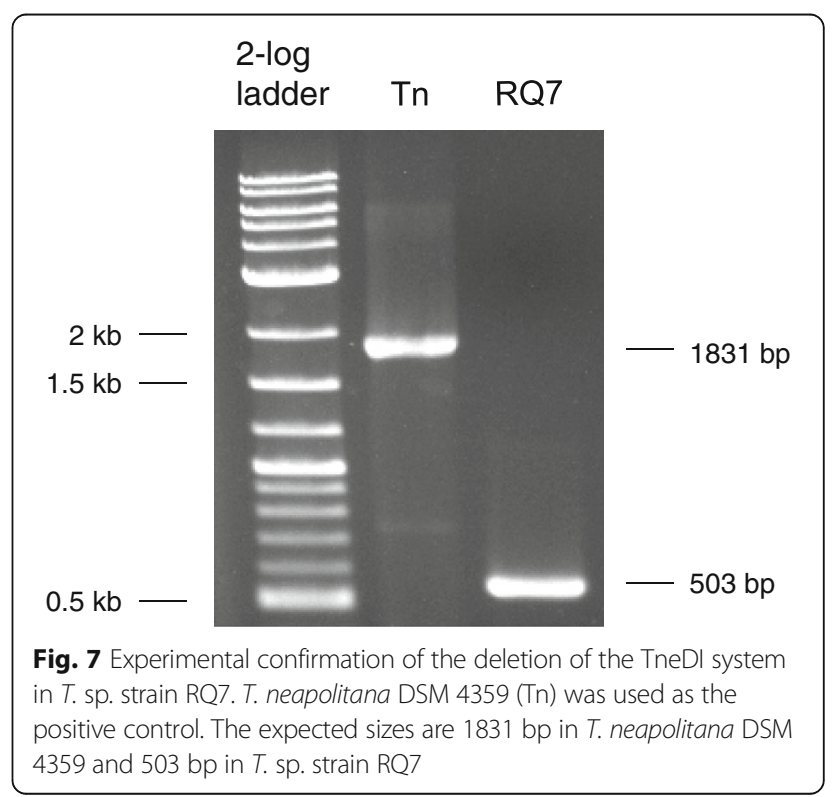




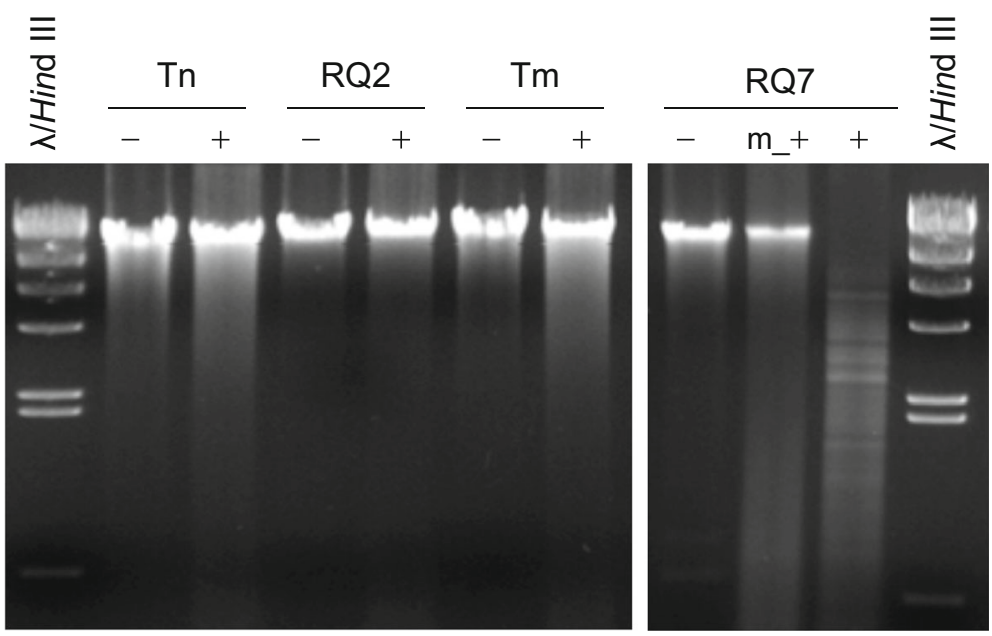

Fig. 8 Digestion of the genomic DNA of T. neapolitana DSM 4359 (Tn), T. sp. strain RQ2 (RQ2), T. maritima MSB8 (Tm), and T. sp. strain RQ7 (RQ7) with R.TneDI. -, negative control, no R.TneDI; +, digestion with R.TneDI; m_+, DNA was treated with M.TneDI prior to being digested by R.TneDI

\section{Conclusions}

The genome of $T$. sp. strain RQ7 shares large regions of synteny with those of its close relatives, namely, $T$. neapolitana DSM 4359, T. maritima MSB8, and T. sp. strain RQ2. They all have a complete set of putative competence genes, although natural transformation has yet to be established in $T$. neapolitana DSM 4359 and T. maritima MSB8. The same number of CRISPR loci are found in all four genomes, even though the number of spacers vary. The most noticeable difference among the strains is the absence of the TneDI R-M system in T. sp. strain RQ7,

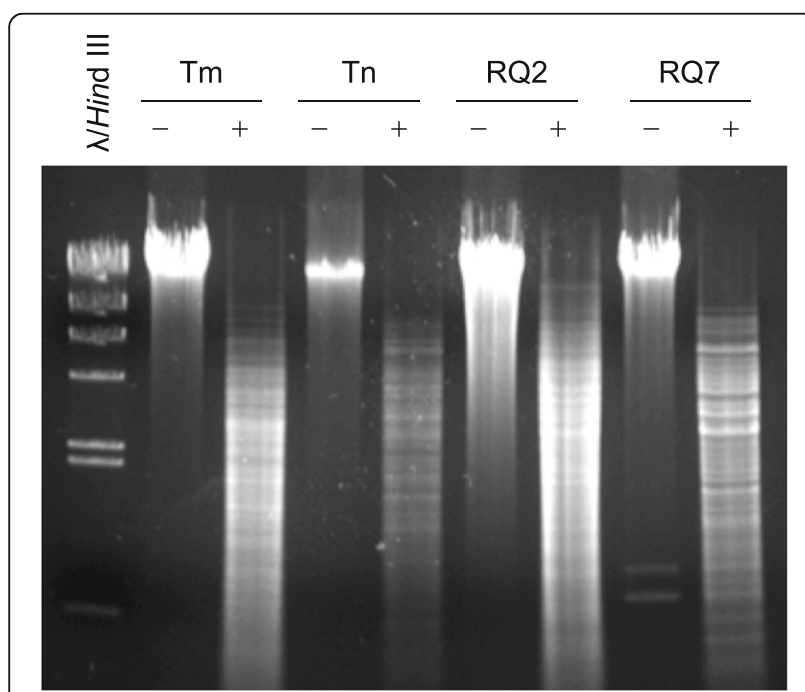

Fig. 9 Digestion of genomic DNA of T. maritima MSB8 (Tm), T. neapolitana DSM 4359 (Tn), T. sp. strain RQ2 (RQ2), and T. sp. strain RQ7 by BstUI. -, negative control, no BstUl; +, treated with BstUI which partially explains why this strain is more amenable to genetic modifications than others. In general, this work sheds light on the genetic features of $T$. sp. strain RQ7, promoting genetic and genomic studies of Thermotoga spp.

\section{Abbreviations}

Cas: CRISPR associated; CRISPR: Clustered regularly interspaced short palindromic repeats; R-M: Restriction-modification

\section{Acknowledgements}

We are grateful to Drs. Harald Huber and Robert Huber at the University of Regensburg, Germany, for kindly providing T. sp. strain RQ7.

\section{Funding}

This work was supported by the BGSU Commercialization Catalyst Award and the BGSU Building Strength Award to ZX. BGSU plays no role in designing or conducting the study, collecting or analysing the data, or writing the manuscript.

\section{Authors' contributions}

ZX conceived and coordinated the study, participated in all aspects of data analysis and drafted the manuscript. RP participated in most parts of the work and helped in writing the manuscript. JX produced the SEM photo and the phylogenetic tree. HX contributed to the R-M study. DH initiated the sequencing project and the R-M study. All authors read and approved the final manuscript.

\section{Competing interests}

The authors declare that they have no competing interests.

\section{Publisher's Note}

Springer Nature remains neutral with regard to jurisdictional claims in published maps and institutional affiliations.

\section{Author details}

${ }^{1}$ Department of Biological Sciences, Bowling Green State University, Bowling Green, OH 43403, USA. ${ }^{2}$ School of Life Sciences, Minnan Normal University, 36 Xianqianzhi Street, Zhangzhou, Fujian 363000, China. 
Received: 4 October 2016 Accepted: 21 September 2017

Published online: 11 October 2017

\section{References}

1. Huber R, Langworthy TA, Konig H, Thomm M, Woese CR, Sleytr UB, Stetter KO. Thermotoga maritima sp. nov. represents a new genus of unique extremely thermophilic eubacteria growing up to 90 degrees C. Arch Microbiol. 1986;144(4):324-33.

2. Schroder C, Selig M, Schonheit P. Glucose Fermentation to Acetate, CO2 and $\mathrm{H}_{2}$ in the Anaerobic Hyperthermophilic Eubacterium Thermotoga Maritima: Involvement of the Embden-Meyerhof Pathway. Arch Microbiol. 1994;161(6):460-70.

3. Takahata Y, Nishijima M, Hoaki T, petrophila MTT. sp. nov. and Thermotoga naphthophila sp. nov., two hyperthermophilic bacteria from the Kubiki oil reservoir in Niigata, Japan. Int J Syst Evol Microbiol. 2001:51:1901-9.

4. Zhaxybayeva O, Swithers KS, Lapierre P, Fournier GP, Bickhart DM, DeBoy RT, Nelson KE, Nesbo CL, Doolittle WF, Gogarten JP, et al. On the chimeric nature, thermophilic origin, and phylogenetic placement of the Thermotogales. Proc Natl Acad Sci U S A. 2009;106(14):5865-70.

5. Nesbo CL, Dlutek M, Doolittle WF. Recombination in thermotoga: Implications for species concepts and biogeography. Genetics. 2006;172(2):759-69.

6. Han D, Norris SM, Xu Z. Construction and transformation of a Thermotoga-E. coli shuttle vector. BMC Biotechnol. 2012;12:2

7. Han D, Xu H, Puranik R, Xu Z. Natural transformation of Thermotoga sp. strain RQ7. BMC Biotechnol. 2014;14:39.

8. Xu H, Han D, Xu Z. Expression of Heterologous Cellulases in Thermotoga sp. Strain RQ2. Biomed Res Int. 2015;2015:304523.

9. Harriott OT, Huber R, Stetter KO, Betts PW, Noll KM. A Cryptic Miniplasmid from the Hyperthermophilic Bacterium Thermotoga Sp Strain Rq7. J Bacteriol. 1994;176(9):2759-62.

10. Frock AD, Notey JS, Kelly RM. The genus Thermotoga: recent developments. Environ Technol. 2010;31(10):1169-81.

11. Windberger E, Huber R, Trincone A, Fricke H, Stetter KO. Thermotoga thermarum sp. nov. and Thermotoga neapolitana occurring in African continental solfataric springs. Arch Microbiol. 1989;151(6):506-12.

12. Rachel R, Engel AM, Huber R, Stetter KO, Baumeister W. A Porin-Type Protein Is the Main Constituent of the Cell-Envelope of the Ancestral Eubacterium Thermotoga-Maritima. FEBS Lett. 1990;262(1):64-8.

13. Angiuoli SV, Gussman A, Klimke W, Cochrane G, Field D, Garrity G, Kodira CD, Kyrpides N, Madupu R, Markowitz V, et al. Toward an online repository of Standard Operating Procedures (SOPs) for (meta)genomic annotation. OMICS. 2008;12(2):137-41.

14. Huntemann M, Ivanova NN, Mavromatis K, Tripp HJ, Paez-Espino D, Palaniappan K, Szeto E, Pillay M, Chen IM, Pati A, et al. The standard operating procedure of the DOE-JGI Microbial Genome Annotation Pipeline (MGAP v.4). Stand Genomic Sci. 2015;10:86.

15. Van Ooteghem SA, Beer SK, Yue PC. Hydrogen production by the thermophilic bacterium Thermotoga neapolitana. Appl Biochem Biotechnol. 2002;98:177-89.

16. Sambrook J, Russell DW. The Condensed Protocols from Molecular Cloning: A Laboratory Manual. New York: Cold Spring Harbor Laboratory Press; 2006.

17. Li R, Zhu H, Ruan J, Qian W, Fang X, Shi Z, Li Y, Li S, Shan G, Kristiansen K, et al. De novo assembly of human genomes with massively parallel short read sequencing. Genome Res. 2010;20(2):265-72.

18. SOAPaligner [http://soap.genomics.org.cn/soapaligner.html]

19. CLC Genomics Workbench [https://www.qiagenbioinformatics.com/ products/clc-genomics-workbench/].

20. Puranik R, Quan G, Werner J, Zhou R, Xu Z. A pipeline for completing bacterial genomes using in silico and wet lab approaches. BMC Genomics. 2015;16(Suppl 3):S7.

21. Yu JS, Noll KM. Plasmid $\mathrm{pRQ7}$ from the hyperthermophilic bacterium Thermotoga species strain $\mathrm{RQ7}$ replicates by the rolling-circle mechanism. J Bacteriol. 1997;179(22):7161-4.

22. Goris J, Konstantinidis KT, Klappenbach JA, Coenye T, Vandamme P, Tiedje JM. DNA-DNA hybridization values and their relationship to whole-genome sequence similarities. Int J Syst Evol Microbiol. 2007:57(Pt 1):81-91.

23. Swithers KS, DiPippo JL, Bruce DC, Detter C, Tapia R, Han S, Saunders E, Goodwin LA, Han J, Woyke T, et al. Genome sequence of Thermotoga sp. strain RQ2, a hyperthermophilic bacterium isolated from a geothermally heated region of the seafloor near Ribeira Quente, the Azores. J Bacteriol. 2011;193(20):5869-70.
24. Sorek R, Kunin V, Hugenholtz P. CRISPR-a widespread system that provides acquired resistance against phages in bacteria and archaea. Nat Rev Microbiol. 2008;6(3):181-6.

25. Garneau JE, Dupuis ME, Villion M, Romero DA, Barrangou R, Boyaval P, Fremaux C, Horvath P, Magadan AH, Moineau S. The CRISPR/Cas bacterial immune system cleaves bacteriophage and plasmid DNA. Nature. 2010;468(7320):67-71.

26. Jorth $P$, Whiteley M. An evolutionary link between natural transformation and CRISPRadaptive immunity. MBio. 2012;3(5):e00309-12.

27. Bikard D, Hatoum-Aslan A, Mucida D, Marraffini LA. CRISPR interference can prevent natural transformation and virulence acquisition during in vivo bacterial infection. Cell Host Microbe. 2012:12(2):177-86.

28. Mongodin EF, Hance IR, DeBoy RT, Gill SR, Daugherty S, Huber R, Fraser CM, Stetter K, Nelson KE. Gene transfer and genome plasticity in Thermotoga maritima, a model hyperthermophilic species. J Bacteriol. 2005;187(14):4935-44.

29. DeBoy RT, Mongodin EF, Emerson JB, Nelson KE. Chromosome evolution in the Thermotogales: Large-scale inversions and strain diversification of CRISPR sequences. J Bacteriol. 2006;188(7):2364-74.

30. Grissa I, Vergnaud G, Pourcel C. CRISPRFinder: a web tool to identify clustered regularly interspaced short palindromic repeats. Nucleic Acids Res. 2007;35(Web Server issue):W52-7.

31. Haft DH, Selengut J, Mongodin EF, Nelson KE. A guild of 45 CRISPR-associated (Cas) protein families and multiple CRISPR/Cas subtypes exist in prokaryotic genomes. PLoS Comput Biol. 2005;1(6):e60.

32. Xu Z, Han D, Cao J, Saini U. Cloning and characterization of the TneDI restriction: modification system of Thermotoga neapolitana. Extremophiles. 2011;15(6):665-72

33. $\mathrm{Xu} \mathrm{H}, \mathrm{Han} \mathrm{D}, \mathrm{Xu}$ Z. Overexpression of a lethal methylase, M.TneDI, in E. coli BL21(DE3). Biotechnol Lett. 2014:36(9):1853-9.

34. Ehrlich M, Gama-Sosa MA, Carreira LH, Ljungdahl LG, Kuo KC, Gehrke CW. DNA methylation in thermophilic bacteria: N4-methylcytosine, 5-methylcytosine, and N6-methyladenine. Nucleic Acids Res. 1985;13(4):1399-412.

35. Jin SG, Kadam S, Pfeifer GP. Examination of the specificity of DNA methylation profiling techniques towards 5-methylcytosine and 5-hydroxymethylcytosine. Nucleic Acids Res. 2010;38(11):e125.

36. Field D, Garrity G, Gray T, Morrison N, Selengut J, Sterk P, Tatusova T, Thomson N, Allen MJ, Angiuoli SV, et al. The minimum information about a genome sequence (MIGS) specification. Nat Biotechnol. 2008;26(5):541-7.

37. Woese CR, Kandler O, Wheelis ML. Towards a natural system of organisms: proposal for the domains Archaea, Bacteria, and Eucarya. Proc Natl Acad Sci U S A. 1990:87(12):4576-9.

38. Reysenbach A-L, BII P. Thermotogae phy.nov. In: Garrity GM, Boone DR, Castenholz RW, editors. Bergey's manual of systematic bacteriology, vol. 1. 2nd ed. New York: Springer; 2001. p. 369-87.

39. List Editor. Validation of the Publication of New Names and New Combinations Previously Effectively Published Outside the IJSB. List No. 85 Int J Syst Bacteriol. 2002;52(3):685-90.

40. Reysenbach A-L, Class I. Thermotogae class. nov. In: Garrity GM, Boone DR Castenholz RW, editors. Bergey's manual of systematic bacteriology, vol. 1. 2nd ed. New York: Springer; 2001. p. 369-87.

41. Reysenbach A-L, Order I. Thermotogales ord. nov. Huber and Stetter 1992C, 3809. In: Garrity GM, Boone DR, Castenholz RW, editors. Bergey's manual of systematic bacteriology, vol. 1. 2nd ed. New York: Springer; 2001. p. 369-87.

42. Reysenbach A-L, Family I. Thermotogaceae fam. nov. In: Garrity GM, Boone DR, Castenholz RW, editors. Bergey's manual of systematic bacteriology, vol. 1. 2nd ed. New York: Springer; 2001. p. 370-87.

43. Bhandari V, Gupta RS. Molecular signatures for the phylum (class) Thermotogae and a proposal for its division into three orders (Thermotogales, Kosmotogales ord. nov. and Petrotogales ord. nov.) containing four families (Thermotogaceae, Fervidobacteriaceae fam. nov., Kosmotogaceae fam. nov. and Petrotogaceae fam. nov.) and a new genus Pseudothermotoga gen. nov. with five new combinations. Antonie Van Leeuwenhoek. 2014:105(1):143-68.

44. List Editor. Validation of the Publication of New Names and New Combinations Previously Effectively Published Outside the IJSB. List No. 22. Int J Syst Bacteriol. 1986;36(4):573-6

45. Jannasch HW, Huber R, Belkin S, Stetter, KO. Thermotoga neapolitana sp. nov. of the extremely thermophilic, eubacterial genus Thermotoga. Arch Microbiol. 1988:150(1):103-4

46. List Editor. Validation of the Publication of New Names and New Combinations Previously Effectively Published Outside the IJSB. List No. 28. Int J Syst Bacteriol. 1989;39(1):93-4 
47. Chhabra SR, Shockley KR, Conners SB, Scott KL, Wolfinger RD, Kelly RM. Carbohydrate-induced differential gene expression patterns in the hyperthermophilic bacterium Thermotoga maritima. J Biol Chem. 2003;278(9):7540-52

48. Yu X, Drapcho CM. Hydrogen production by the hyperthermophilic bacterium Thermotoga neapolitana using agricultural-based carbon and nitrogen sources. Biol Eng Trans. 2011;4(2):101-12.

49. Ashburner M, Ball CA, Blake JA, Botstein D, Butler H, Cherry JM, Davis AP, Dolinski K, Dwight SS, Eppig JT, et al. Gene ontology: tool for the unification of biology. The Gene Ontology Consortium. Nat Genet. 2000;25(1):25-9.

50. Kumar S, Stecher G, Tamura K. MEGA7: Molecular Evolutionary Genetics Analysis Version 7.0 for Bigger Datasets. Mol Biol Evol. 2016;33(7):1870-4

51. Besemer J, Lomsadze A, Borodovsky M. GeneMarkS: a self-training method for prediction of gene starts in microbial genomes. Implications for finding sequence motifs in regulatory regions. Nucleic Acids Res. 2001;29(12):2607-18.

52. Hyatt D, Chen GL, Locascio PF, Land ML, Larimer FW, Hauser LJ. Prodigal: prokaryotic gene recognition and translation initiation site identification. BMC Bioinformatics. 2010;11:119.

53. Darling AC, Mau B, Blattner FR, Perna NT. Mauve: multiple alignment of conserved genomic sequence with rearrangements. Genome Res. 2004;14(7):1394-403.

54. Alm RA, Bodero AJ, Free PD, Mattick JS. Identification of a novel gene, pilZ, essential for type 4 fimbrial biogenesis in Pseudomonas aeruginosa. J Bacteriol. 1996;178(1):46-53.

55. van Schaik EJ, Giltner CL, Audette GF, Keizer DW, Bautista DL, Slupsky CM, Sykes BD, Irvin RT. DNA binding: a novel function of Pseudomonas aeruginosa type IV pili. J Bacteriol. 2005;187(4):1455-64.

56. Pratt JT, Tamayo R, Tischler AD, Camilli A. PilZ domain proteins bind cyclic diguanylate and regulate diverse processes in Vibrio cholerae. J Biol Chem. 2007;282(17):12860-70.

57. Chiang P, Sampaleanu LM, Ayers M, Pahuta M, Howell PL, Burrows LL. Functional role of conserved residues in the characteristic secretion NTPase motifs of the Pseudomonas aeruginosa type IV pilus motor proteins PilB, PilT and PilU. Microbiology. 2008;154(Pt 1):114-26.

58. Nunn D, Bergman S, Lory S. Products of three accessory genes, pilB, pilC, and pilD, are required for biogenesis of Pseudomonas aeruginosa pili. J Bacteriol. 1990;172(6):2911-9.

59. Seitz P, Blokesch M. DNA-uptake machinery of naturally competent Vibrio cholerae. Proc Natl Acad Sci U S A. 2013;110(44):17987-92.

60. Assalkhou R, Balasingham S, Collins RF, Frye SA, Davidsen T, Benam AV, Bjoras M, Derrick JP, Tonjum T. The outer membrane secretin PilQ from Neisseria meningitidis binds DNA. Microbiology. 2007;153(Pt 5):1593-603.

61. Burkhardt J, Vonck J, Averhoff B. Structure and function of PilQ, a secretin of the DNA transporter from the thermophilic bacterium Thermus thermophilus HB27. J Biol Chem. 2011;286(12):9977-84.

62. Collins RF, Davidsen L, Derrick JP, Ford RC, Tonjum T. Analysis of the PilQ secretin from Neisseria meningitidis by transmission electron microscopy reveals a dodecameric quaternary structure. J Bacteriol. 2001;183(13):3825-32.

63. Graupner S, Frey V, Hashemi R, Lorenz MG, Brandes G, Wackernagel W. Type IV pilus genes pilA and pilC of Pseudomonas stutzeri are required for natural genetic transformation, and pilA can be replaced by corresponding genes from nontransformable species. J Bacteriol. 2000;182(8):2184-90.

64. Rudel T, Facius D, Barten R, Scheuerpflug I, Nonnenmacher E, Meyer TF. Role of pili and the phase-variable PilC protein in natural competence for transformation of Neisseria gonorrhoeae. Proc Natl Acad Sci U S A. 1995:92(17):7986-90.

65. Nunn DN, Lory S. Product of the Pseudomonas aeruginosa gene pilD is a prepilin leader peptidase. Proc Natl Acad Sci U S A. 1991;88(8):3281-5.

66. Freitag NE, Seifert HS, Koomey M. Characterization of the pilF-pilD pilusassembly locus of Neisseria gonorrhoeae. Mol Microbiol. 1995;16(3):575-86.

67. Paranjpye RN, Lara JC, Pepe JC, Pepe CM, Strom MS. The type IV leader peptidase/N-methyltransferase of Vibrio vulnificus controls factors required for adherence to HEp-2 cells and virulence in iron-overloaded mice. Infect Immun. 1998;66(12):5659-68.

68. Hahn J, Inamine G, Kozlov Y, Dubnau D. Characterization of comE, a late competence operon of Bacillus subtilis required for the binding and uptake of transforming DNA. Mol Microbiol. 1993;10(1):99-111.

69. Draskovic I, Dubnau D. Biogenesis of a putative channel protein, ComEC, required for DNA uptake: membrane topology, oligomerization and formation of disulphide bonds. Mol Microbiol. 2005:55(3):881-96.
70. Bakaletz LO, Baker BD, Jurcisek JA, Harrison A, Novotny LA, Bookwalter JE, Mungur R, Munson RS Jr. Demonstration of Type IV pilus expression and a twitching phenotype by Haemophilus influenzae. Infect Immun. 2005;73(3):1635-43.

71. Larson TG, Goodgal SH. Sequence and transcriptional regulation of com101A, a locus required for genetic transformation in Haemophilus influenzae. J Bacteriol. 1991;173(15):4683-91.

72. Wolfgang M, Lauer P, Park HS, Brossay L, Hebert J, Koomey M. PilT mutations lead to simultaneous defects in competence for natural transformation and twitching motility in piliated Neisseria gonorrhoeae. Mol Microbiol. 1998:29(1):321-30.

73. Kline KA, Criss AK, Wallace A, Seifert HS. Transposon mutagenesis identifies sites upstream of the Neisseria gonorrhoeae pilE gene that modulate pilin antigenic variation. J Bacteriol. 2007;189(9):3462-70.

74. Russell MA, Darzins A. The pilE gene product of Pseudomonas aeruginosa, required for pilus biogenesis, shares amino acid sequence identity with the N-termini of type 4 prepilin proteins. Mol Microbiol. 1994;13(6):973-85.

75. Provvedi R, Dubnau D. ComEA is a DNA receptor for transformation of competent Bacillus subtilis. Mol Microbiol. 1999:31(1):271-80.

76. Inamine GS, Dubnau D. ComEA, a Bacillus subtilis integral membrane protein required for genetic transformation, is needed for both DNA binding and transport. J Bacteriol. 1995;177(11):3045-51.

77. Chen I, Gotschlich EC. ComE, a competence protein from Neisseria gonorrhoeae with DNA-binding activity. J Bacteriol. 2001;183(10):3160-8.

78. Takeno M, Taguchi H, Akamatsu T. Role of ComEA in DNA uptake during transformation of competent Bacillus subtilis. J Biosci Bioeng. 2012;113(6):689-93.

79. Gwinn ML, Ramanathan R, Smith HO, Tomb JF. A new transformation-deficient mutant of Haemophilus influenzae Rd with normal DNA uptake. J Bacteriol. 1998;180(3):746-8.

80. Mortier-Barriere I, Velten M, Dupaigne P, Mirouze N, Pietrement O, McGovern S, Fichant G, Martin B, Noirot P, Le Cam E, et al. A key presynaptic role in transformation for a widespread bacterial protein: DprA conveys incoming ssDNA to RecA. Cell. 2007;130(5):824-36.

81. Karudapuram S, Zhao X, Barcak GJ. DNA sequence and characterization of Haemophilus influenzae dprAt, a gene required for chromosomal but not plasmid DNA transformation. J Bacteriol. 1995;177(11):3235-40.

82. Clone Manager [http://www.scied.com/index.htm]

\section{Submit your next manuscript to BioMed Central and we will help you at every step:}

- We accept pre-submission inquiries

- Our selector tool helps you to find the most relevant journal

- We provide round the clock customer support

- Convenient online submission

- Thorough peer review

- Inclusion in PubMed and all major indexing services

- Maximum visibility for your research

Submit your manuscript at www.biomedcentral.com/submit
C) Biomed Central 